\title{
Quantitative Assessment of Remotely Sensed Data for Landcover Change and Environmental Management.
}

\author{
Innocent E. BELLO, Momoh L. RILWANI
}

Received: 30112015 / Accepted: 1504 2016 / Published online: 30122016

C 2016 Faculty of Geography UGM and The Indonesian Geographers Association

\begin{abstract}
This paper examines the relevance and application of quantitative techniques in geographic study with emphasis on landcover change and environmental management in a typical urban city of Warri and its environs in Nigeria. It uses an experimental study that adopts Principal Component Analysis (PCA) and Accuracy Assessment in reducing data dimensions and enhancing image visualization for onward classification into landcover classes using 1987 TM, 2002 ETM+ and ETM+ 2011. The 2011 ETM+ was later excluded due to scan line and cloud cover errors. The PCA results show that 1987 Bands of 145 has variance of 834.71 (88.09\% of total components) while the 2002 Bands of 147 has variance of 1287.21 ( $85.344 \%$ of total components). Supervised classification results show overall accuracy of $96.19 \%$ (for 1987) and $96.30 \%$ (for 2002) respectively. The study reveals that there was increase in urban landcover $(17.2 \%$ to $34.93 \%)$ and swamp (10.11\% to $11.61 \%)$. Correspondingly, light vegetation and thick vegetation decreased from $41.76 \%$ to $27.38 \%$ and $26.31 \%$ to $22.36 \%$ while water also reduced from $4.63 \%$ to $3.73 \%$. The study indicates a higher demand for urban settlement which requires landuse control to avoid urban blight and environmental decay.
\end{abstract}

Keywords: Environment, Geographic study, Landcover, PCA Quantitative Technique, Remote Sensing

Abstrak Makalah ini membahas relevansi dan penerapan teknik kuantitatif dalam penelitian geografis dengan penekanan pada perubahan tutupan lahan dan pengelolaan lingkungan di kota urban khas Warri dan sekitarnya di Nigeria. Menggunakan studi eksperimental yang mengadopsi Principal Component Analysis (PCA) dan Penilaian Akurasi dalam mengurangi dimensi data dan meningkatkan visualisasi gambar untuk seterusnya klasifikasi ke dalam kelas tutupan lahan menggunakan 1987 TM 2002 ETM + dan ETM + 2011. 2011 ETM + kemudian dikeluarkan karena garis scan dan kesalahan awan. Hasil PCA menunjukkan bahwa 1.987 Bands dari 145 memiliki varians dari 834,71 (88,09\% dari total komponen) sedangkan 2002 Bands dari 147 memiliki varians dari 1.287,21 (85,344\% dari total komponen). Hasil klasifikasi diawasi menunjukkan akurasi keseluruhan masing-masing 96,19\% (untuk 1987) dan 96,30\% (tahun 2002). Penelitian ini mengungkapkan bahwa ada peningkatan tutupan lahan perkotaan (17,2\% menjadi 34,93\%) dan rawa (10.11\% menjadi 11,61\%). Sejalan dengan itu, vegetasi ringan dan vegetasi tebal menurun dari 41,76\% menjadi $27,38 \%$ dan 26,31\% untuk 22,36\% sementara air juga berkurang dari 4,63\% menjadi 3,73\%. Studi ini menunjukkan permintaan yang lebih tinggi untuk pemukiman perkotaan yang membutuhkan kontrol penggunaan lahan untuk menghindari hawar perkotaan dan pembusukan lingkungan.

Kata kunci: Lingkungan, studi Geographic, tutupan lahan, PCA Teknik Kuantitatif, Remote Sensing

\section{Introduction}

Literature reveals that spatial phenomen in the environment are vast and complex.

Innocent E. BELLO, Momoh L. RILWANI

National Space Research and Development Agency

(NASRDA), Obasanjo Space Centre, Airport Road, PMB 437,

Garki 2, Abuja, Nigeria

Email: innobello@yahoo.com
These phenomena can be measured and represented in various ways as anything anywhere, whether tangible or intangible can be mapped because they have location of occurrence and are spatial in nature [Robinson \& Sale, 1982; Rilwani, 2006]. Since the late 1940s, the emergence of 'Scientific Geography' which emphasises the significance of precise measurements and accurate presentation of results is, in part, responsible for the 
application of statistical methods to geographic studies at all levels of scientific investigations [Akinbode, 1996].

A common denominator of all the sciences is the sources and methods of data collection on one hand, and methods of data analysis on the other hand. The paradigm shift in digital geographic data collection, quantitative data analysis, classification and presentation has increased the confidence level placed on research findings [Onokerhoraye, 1994].

Harris, et al. [2013] argued that quantitative methods broadly mean data collection, analysis and presentations, which includes Remote Sensing. Remotely sensed data is a kind of digital picture that covers part or all of the earth as obtained from sensor(s) attached to satellite in space. The use of statistics such as the Principal Component Analysis (PCA) in aggregating and compressing geographic data into meaningful information Wyly [2001] has found relevance in many applications. These include applications in remotely sensed hyperspectral imaging Rodarmel \& Shan [2002], multispectral image studies such as landuse and landcover analyses Das [na], rainfall analysis Fowdur, Vir Ruhgooputh, Cheeneebash, Boojhanon \& Gopaul [2014] and, meteorology and oceanography [Preisendorfer, 1988]. Thus, factors that have led to the popularity of PCA in recent years include its simplicity, ease of use, as part of popular remotesensing and statistical packages, and optimal nature in terms of mean square error [Preisendorfer, 1988].

Basically, PCA was invented in 1901 by Karl Pearson [Pearson, 1901], as an analogue of the principal axis theorem in mechanics; it was later independently developed (and named) by Harold Hotelling in the 1930s [Hotelling, 1933]. According to Jolliffe [2002], PCA “is mathematically defined as an orthogonal linear transformation that transforms the data to a new coordinate system such that the greatest variance by some projection of the data comes to lie on the first coordinate (called the first principal component), the second greatest variance on the second coordinate, and so on". As illustrated by Jolliffe [2002], PCA transformation is defined by a set of $\mathrm{p}$-dimensional vectors of weights or loadings $\mathrm{W}[\mathrm{k}]=[\mathrm{wi}, \ldots, \mathrm{wp}][\mathrm{k}]$ that map each row vector $\mathrm{X}[\mathrm{i}]$ of $\mathrm{X}$ to a new vector of principal component scores $\mathrm{t}[\mathrm{i}]=[\mathrm{t} 1, \ldots, \mathrm{tp}][\mathrm{i}]$, , given by

$$
\mathrm{tk}[\mathrm{i}]=\mathrm{X}[\mathrm{i}]{ }^{\star} \mathrm{W}[\mathrm{k}]
$$

in such a way that the individual variables of $t$ considered over the data set successively inherit the maximum possible variance from $\mathrm{x}$, with each loading vector $\mathrm{w}$ constrained to be a unit vector [Jolliffe, 2002].

Thus, the first loading vector $\mathrm{w}[1]$ thus has to satisfy

$$
\mathbf{w}_{(1)}=\underset{\|\mathbf{w}\|=1}{\arg \max }\left\{\sum_{i}\left(t_{1}\right)_{(i)}^{2}\right\}=\underset{\|\mathbf{w}\|=1}{\arg \max }\left\{\sum_{i}\left(\mathbf{x}_{(i)} \cdot \mathbf{w}\right)^{2}\right\}
$$

Equivalently, writing this in matrix form gives $\mathbf{w}_{(1)}=\underset{\|\mathbf{w}\|=1}{\arg \max }\left\{\|\mathbf{X} \mathbf{w}\|^{2}\right\}=\underset{\|\mathbf{w}\|=1}{\arg \max }\left\{\mathbf{w}^{T} \mathbf{X}^{T} \mathbf{X} \mathbf{w}\right\}$

Since $\mathrm{w}\left[{ }_{1}\right]$ has been defined to be a unit vector, it equivalently also satisfies

$$
\mathbf{w}_{(1)}=\arg \max \left\{\frac{\mathbf{w}^{T} \mathbf{X}^{T} \mathbf{X} \mathbf{w}}{\mathbf{w}^{T} \mathbf{w}}\right\}
$$

The quantity to be maximised can be recognised as a 'Rayleigh quotient'. A standard result for a symmetric matrix such as $\mathrm{X}^{\mathrm{T}} \mathrm{X}$ is that the quotient's maximum possible value is the largest eigenvalue of the matrix, which occurs when $w$ is the corresponding eigenvector. With $\mathrm{w}_{[1]}$ found, the first component of a data vector $\mathbf{x}_{[1]}$ can then be given as a score $\boldsymbol{t}_{1[\mathrm{i}]}=\mathbf{x}_{[1]} \cdot \mathrm{w}_{[1]}$ in the transformed coordinates, or as the corresponding vector in the original variables, $\left\{\mathrm{x}_{[1]} \cdot \mathrm{w}_{[1]}\right\} \mathrm{w}_{[1]}$. Thus, other components of required dimensionality follow in sequence.

Supporting argument and justification for PCA application in geographic study is that, once variables are correlated, the transformation and reduction of the correlations to a geometric structure with known properties (usually Euclidean) requires the application of PCA [Onokerhoraye, 1994].

Beginning with the pioneering work in geography employing quantitative methods in classification carried out by Berry Berry [1958], the assumption behind quantification as argued by Peter Haggett, Richard Chorldey and David Harvey Balsley [1970] is that there is an objective truth existing in the world that can be measured and explained scientifically [Matveev, 2002]. Measurement is reliable, valid, and generalizable in its clear prediction of cause and effect [Cassell \& Symon, 1994; Kealey \& Protheroe, 1996]. In other words, many scholars have employed quantitative methods and remote sensing in various forms of 
classification activities Onokerhoraye [1994] for which Landuse/Landcover change analysis is a major field of applications [Berry, 1958; Turner, et al., 1995; Feranec, Otahel and Pravda, 1998; Rodarmel and Shan, 2002; Matveer, 2002; Das, na]. Scholars that have worked on PCA applications also include [Fowdur et al. 2014; Bäring, 1988; Richman, 1986; Overland \& Preisendorfer, 1982; Bedi \& Bindra, 1980; and Daultrey, 1976].

The relevance of PCA in image analysis and change detection includes data compression and image enhancement [see Helmy \& El-Taweel, 2009; Rodarmel \& Shan, 2002]. Since multispectral image data is usually strongly correlated from one band to the other, the level of a given picture element on one band can, to some extent, be predicted from the level of that same pixel in another band [Kumar, na]. Increasing the number of layers (data dimension) in remotely sensed geographic data often does not result in the same increase in information content as there will be layers that correlate to each other, so pixels [picture elements] with high value on one channel will have high values on others too [Janos, 2009].

Remote sensing studies integrating PCA in the study of landcover and the biophysical state of the earth's surface and immediate subsurface Turner et al. [1995], especially in Nigeria, are still very limited. As a proof-of-concept, the techniques of PCA is incorporated as a special transformation in digital image processing of satellite images of Warri and its environs where a number of correlated bands of the image data will be reduced to few uncorrelated bands. The basis of PCA is to linearly transform the layers, so that the correlation between layers will be as low as possible, and then to choose from the newly made layers the ones within which the variance of the pixels is the highest, and this show the most information and the transformation functions are determined during the training stage [see Das, na; Rodarmel \& Shan, 2002]. The aim of the study, therefore, is to examine the application of PCA analysis in the classification of remotely sensed data for landcover change analysis of Warri and its environs in the Niger Delta region of Southern Nigeria.

The specific objectives are to:

i) apply PCA in the reduction of remotely sensed data bands into uncorrelated transformation coefficient required for landcover classification and analysis, ii) use the PCA raster result to carryout landcover classification and analysis and,

iii) examine the nature of observed landcover change pattern in relation to landuse optimization

\section{The Methods}

Warri (the study area) is regarded as one of the oldest riverside area of the Niger Delta region of Nigeria having one of the foremost sea ports [Ibe, Alagbe and Egharevba, 2012]. The study area in UTM coordinate system is located within Latitudes $5027^{\prime} 9.5^{\prime \prime} \mathrm{N}$ and $5036^{\prime} 40.3^{\prime \prime} \mathrm{N}$ and Longitudes 50 $39^{\prime} 19^{\prime \prime} \mathrm{E}$ and $5054^{\prime} 18.6$ " E respectively [figure 1]. It is situated in a relatively flat topography having between 3-6m height above the sea level. It has a sedimentary geologic formation similar to the Ataka, Benin and Somebreibo Warri Deltaic Sand.

The soils are generally sandy and silt with high percolation and low retention of water with some clay-loamy layers. The porosity of the soil is partly responsible for the continual flooding of the region. In addition, the terrain of the region is inundated by several creeks to the North from Ekurede areas, to the west and north is a natural boundary provided by the Crewford (Tori) creek. It's annual rainfall range between $1524-2699 \mathrm{~mm}$ with a temperature as high as $360 \mathrm{C}$ during dry season and as low as 280C during raining season. This makes the area often marshy or swampy most of the year.

The City is linked to Benin City to the North and other parts of Nigeria by major roads, specifically the East-West Road coming from Lagos to Cross River state. With major interconnectivity and population upsurge, the region has continually witnessed unprecedented increase in population since the discovery of oil. Being a major hub of crude oil activities, the influx of people into the region has brought about urban expansion, and going by the 2006 Census, the city population is put around 303,410 . Thus, the geography of Warri together with the anthropogenic activity mix of the people partly affects the nature of land cover and landuse under review.

Landsat images of 1987, 2002 and 2011 with spatial resolutions of $30 \mathrm{~m}$ respectively were used to carryout change detection analysis on the nature of land cover of Warri and its environs. The full image scene of Path 189 and Row 056 was sub-mapped in ILWIS software using the UTM corner coordinates as Upper Left: $129882 \mathrm{~m} \mathrm{E,} 621421 \mathrm{~m} \mathrm{~N}$, and Lower 
Right: $151405 \mathrm{~m}$ E and $602813 \mathrm{~m} \mathrm{~N}$ respectively. PCA generated from Map List (combination of bands) was used to compress image and determine the bands with the highest spectral information for the spatial classes to be classified. Digital training site selections for both images were carried out with the aids of computer (semi-automatic method) using Integrated and Land and Water Information System (ILWIS) software. For the supervised classification carried out, five classes of Built-up, Light Vegetation, Swamp, Thick Vegetation and Water were categorized accordingly using the Maximum Likelihood classifier. Since classification is incomplete without accuracy assessment, the results of the image classifications were examined to provide the level of reliability of the result. Thereafter, image histogram showing the frequency of each Landcover information class in terms of pixel number, percentage and area composition was created for both years. From the result of classified images, the land cover change detection analysis was carried out using image Differencing and Cross Tabulation. Image Differencing is a technique by which registered images acquired at different times have pixel DN values for one band subtracted from the corresponding pixel DN values from the same band in the second image to produce a residual image, which represents the change between the two dates [Mas, 1999]. The subtraction results in positive or negative values in areas of cover change and zero values in areas of no change. Similarly, the Cross Tabulation result for both years under review were examined and the observed changes in terms of land cover increase (gain) and decrease (loss) were evaluated using ILWIS software and graphical representation of results were implemented and the resulting map visualized using ArcGIS software.

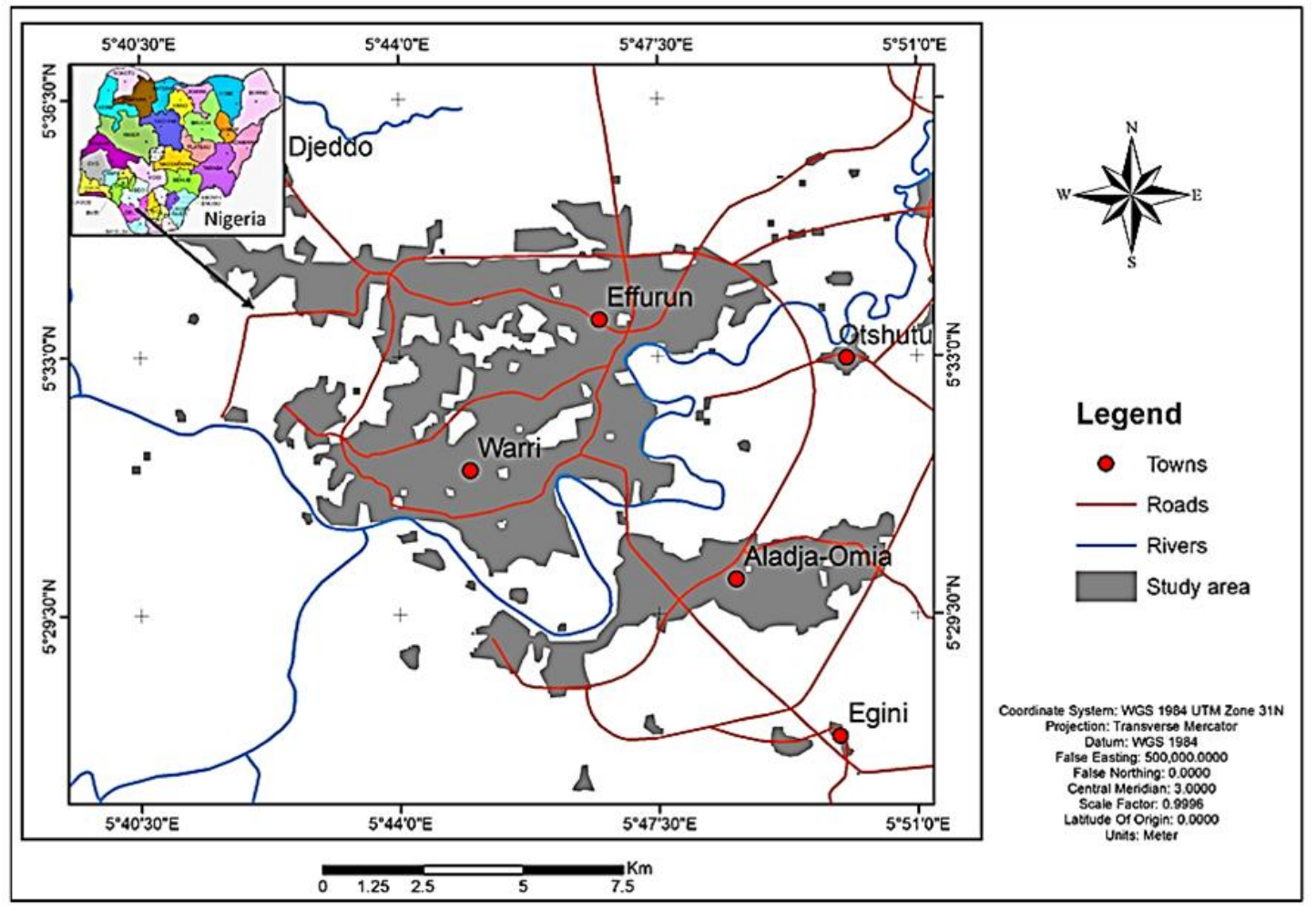

Figure 1. The Study Area

\section{Results and Discussion}

The input for the PCA analysis consists of a map list with raster maps from which the covariance matrix was calculated (table 1). The PCA analyses show the highest index rankings for 1987 and 2002 to be $48.31 \%$ for bands 145 and $63.87 \%$ for bands 147 respectively. The $2011 \mathrm{ETM}+$ was excluded due to scan line error and cloud cover. The result of the PCA operation shows an output matrix denoting the transformation coefficients calculated from the covariance matrix as shown in Tables $2 \mathrm{a}$ and $\mathrm{b}$ respectively, and the output map list containing the set of transformed raster maps [also called the components as shown in Figures 2 . The study reveals that Bands 1-4-5 gave a variance of 834.71 amounting to $88.09 \%$ of the total components for the 1987 epoch while 
Bands 1-4-7 gave a variance of 1287.21 amounting to $85.34 \%$ for the 2002 epoch.

The implication of PCA analysis in this study is that the PCA was carried out for two main reasons: data compression and visual enhancement. That is, the Landsat remotely sensed image used for this study had seven (7 - TM) and eight ( 8 - ETM+) Bands respectively. Bands 6 and 8 were not considered because bands 6 (thermal infrared) and 8
(Panchromatic) do not have the same spatial resolution with other bands and as such cannot fit into the geometric pixel shape required in carrying out PCA for classification and change detection analysis. Whether for data compression or image enhancement, the application of PCA raster map as uncorrelated inputs in further classifying the Warri landcover into information classes is aimed at further increasing classification accuracies.

Table 1. PCA Map list Index Ranking

\begin{tabular}{|c|c|c|c|c|}
\hline 1987 Index Ranking & $1^{\text {st }}$ Band & $2^{\text {nd }}$ Band & $3^{\text {rd }}$ Band & \% composition \\
\hline $1^{\text {st }}$ & 1 & 4 & 5 & 48.31 \\
\hline $2^{\text {nd }}$ & 1 & 4 & 7 & 38.04 \\
\hline $3^{\text {rd }}$ & 3 & 4 & 5 & 34.94 \\
\hline $4^{\text {th }}$ & 2 & 4 & 5 & 34.07 \\
\hline $5^{\text {th }}$ & 3 & 4 & 7 & 28.21 \\
\hline $6^{\text {th }}$ & 1 & 3 & 4 & 27.57 \\
\hline 2002 Index Ranking & $1^{\text {st }}$ Band & $2^{\text {nd }}$ Band & $3^{\text {rd }}$ Band & \% composition \\
\hline $1^{\text {st }}$ & 1 & 4 & 7 & 63.87 \\
\hline $2^{\text {nd }}$ & 1 & 4 & 5 & 54.38 \\
\hline $3^{\mathrm{rd}}$ & 2 & 4 & 7 & 52.94 \\
\hline $4^{\text {th }}$ & 3 & 4 & 7 & 52.24 \\
\hline $5^{\text {th }}$ & 3 & 4 & 5 & 47.31 \\
\hline $6^{\text {th }}$ & 2 & 4 & 5 & 46.60 \\
\hline
\end{tabular}

Source: Authors' Lab work; Note the decreasing Index ranking

Table 2a. 1987 PCA Transformation Coefficients

\begin{tabular}{ccccccc}
\hline 1987 PC & Band 1 & Band 2 & Band 3 & Band 4 & Band 5 & Band 7 \\
\hline PC 1 & 0.070 & 0.056 & 0.130 & 0.159 & 0.823 & 0.522 \\
PC 2 & -0.345 & -0.187 & -0.400 & 0.698 & 0.218 & -0.389 \\
PC 3 & 0.489 & 0.265 & 0.428 & 0.658 & -0.272 & 0.028 \\
PC 4 & 0.362 & 0.134 & 0.193 & -0.231 & 0.449 & -0.747 \\
PC 5 & 0.706 & -0.243 & -0.652 & -0.015 & -0.017 & 0.125 \\
PC 6 & 0.082 & -0.903 & 0.421 & 0.028 & -0.003 & -0.023 \\
Variance & 828.16 & 90.96 & 21.41 & 4.67 & 1.88 & 0.49 \\
\% Variance & 87.40 & 9.60 & 2.26 & 0.49 & 0.20 & 0.05 \\
\hline
\end{tabular}

Table 2b. 2002 PCA Transformation Coefficients

\begin{tabular}{ccccccc}
\hline 2002 PC & Band 1 & Band 2 & Band 3 & Band 4 & Band 5 & Band 7 \\
\hline PC 1 & 0.091 & 0.126 & 0.253 & 0.079 & 0.683 & 0.663 \\
PC 2 & -0.286 & -0.322 & -0.525 & 0.570 & 0.418 & -0.198 \\
PC 3 & -0.375 & -0.410 & -0.381 & -0.650 & 0.002 & 0.351 \\
PC 4 & 0.203 & 0.077 & 0.007 & -0.491 & 0.594 & -0.599 \\
PC 5 & 0.754 & 0.081 & -0.616 & -0.018 & -0.077 & 0.198 \\
PC 6 & -0.400 & 0.836 & -0.368 & -0.064 & 0.012 & 0.032 \\
Variance & 1276.63 & 167.36 & 49.33 & 8.72 & 4.40 & 1.86 \\
\% Variance & 84.64 & 11.10 & 3.27 & 0.58 & 0.29 & 0.12 \\
\hline
\end{tabular}

Source: Authors' Labwork; Note the decreasing Index ranking 

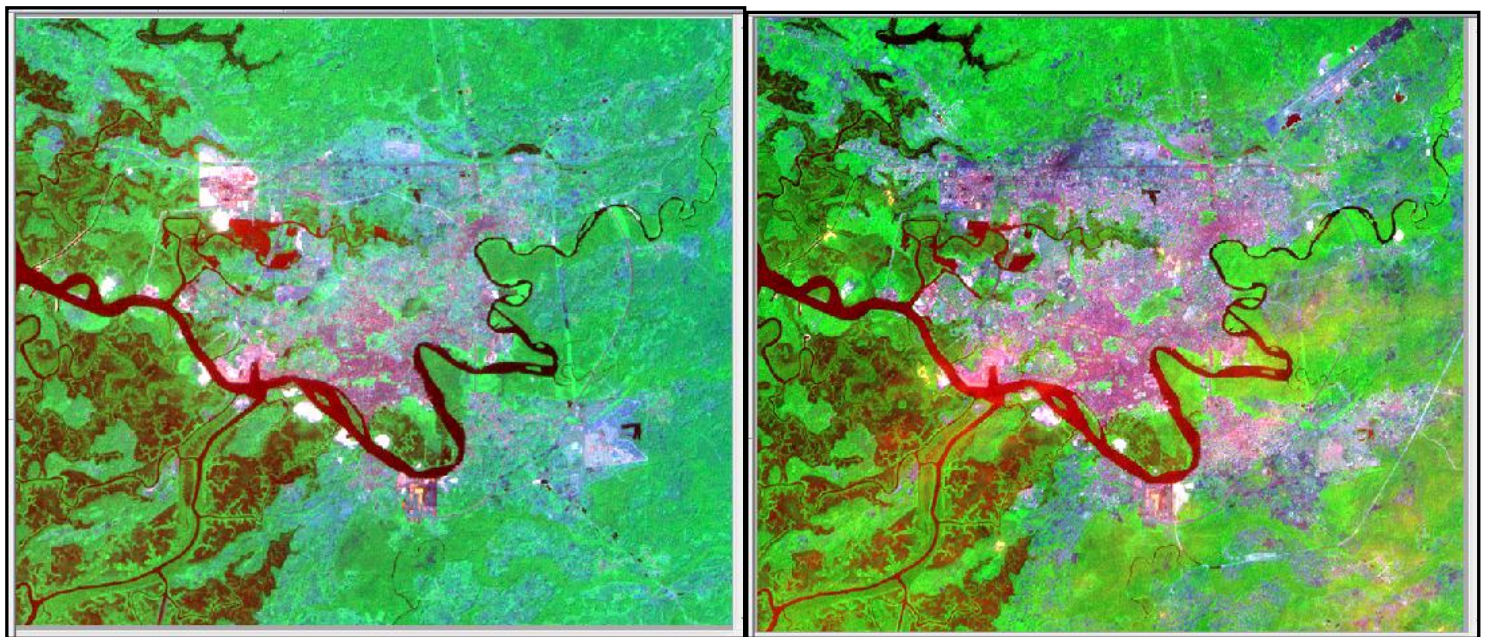

Figure 2. [Left] 1987 PCA Output raster map (B-145), [Right]: 2002 PCA Output raster map (B-147)

The implication of PCA analysis in this study is that the PCA was carried out for two main reasons: data compression and visual enhancement. That is, the Landsat remotely sensed image used for this study had seven $(7-\mathrm{TM})$ and eight (8 - ETM+) Bands respectively. Bands 6 and 8 were not considered because bands 6 [thermal infrared] and 8 (Panchromatic) do not have the same spatial resolution with other bands and as such cannot fit into the geometric pixel shape required in carrying out PCA for classification and change detection analysis. Whether for data compression or image enhancement, the application of PCA raster map as uncorrelated inputs in further classifying the Warri landcover into information classes is aimed at further increasing classification accuracies.

\section{Supervised Classification, Change Detection Analysis and Accuracy Assessment}

Resulting from the PCA analyses, the bands with the highest rankings for both years under review were combined and used to carryout supervised classification in order to further examine the changes that occurred between 1987 and 2002. Table 3 and figure 3 shows that light vegetation accounted for the highest landcover (41.76\%) in 1987, followed by thick vegetation $(26.31 \%)$ and built up (17.20\%) while water was the least cover (4.63\%). Similarly, for the examined 2002 period, figure 5 shows that built-up increased drastically accounting for the highest land cover (34.93\%) closely followed by light vegetation $(23.78 \%)$ while water (river or drainages accounted for the least cover with $3.73 \%$. The image difference shows that two land covers (built-up and swamp) increased while three land covers (light vegetation, thick vegetation and Water) decreased. Table 4 and figure 4 further reveal that Built-up increased the most $(+17.73 \%)$ and slightly followed by Swamp $(+1.5 \%)$. Also, light vegetation decreased the most $(-14.36 \%)$ followed by thick vegetation ($3.93 \%)$ while water cover is the least landcover that decreased $(-0.9 \%)$ in Warri and its environs for the period examined. The thematic andcover map of the study area is shown in figure 5 .

Table 3.1 Percentage Composition and Image Difference between 1987 and 2002 Land Cover

\begin{tabular}{|c|c|c|c|c|c|c|}
\hline Landcover & $\begin{array}{c}1987 \\
\text { Area }\left[\mathrm{m}^{2}\right]\end{array}$ & $\begin{array}{c}1987 \% \\
\text { Composition }\end{array}$ & $\begin{array}{c}2002 \\
\text { Area }\left[\mathrm{m}^{2}\right]\end{array}$ & $\begin{array}{c}2002 \% \\
\text { Composition }\end{array}$ & $\begin{array}{c}\text { Landcover } \\
\text { Changes [ha] }\end{array}$ & $\begin{array}{c}\% \\
\text { Change }\end{array}$ \\
\hline 1. Built-up & 68917500 & 17.20 & 139959900 & 34.93 & 7104.2 & +17.73 \\
\hline $\begin{array}{ll}\text { 2. Light } \\
\text { Vegetation }\end{array}$ & 167328900 & 41.76 & 109710000 & 27.38 & -5761.9 & -14.36 \\
\hline 3. Swamp & 40500900 & 10.11 & 46511100 & 11.61 & 601.0 & +1.5 \\
\hline $\begin{array}{l}\text { 4. Thick } \\
\text { Vegetation }\end{array}$ & 105413400 & 26.31 & 89616600 & 22.36 & -1579.7 & -3.93 \\
\hline $\begin{array}{l}\text { 5. Water } \\
\text { Total }\end{array}$ & $\begin{array}{c}18570600 \\
400731300\end{array}$ & $\begin{array}{l}4.63 \\
100\end{array}$ & $\begin{array}{c}14933700 \\
400731300\end{array}$ & $\begin{array}{r}3.73 \\
100\end{array}$ & $\begin{array}{c}-363.7 \\
0\end{array}$ & $\begin{array}{c}-0.9 \\
0\end{array}$ \\
\hline
\end{tabular}

Source: Authors' Computer Result 


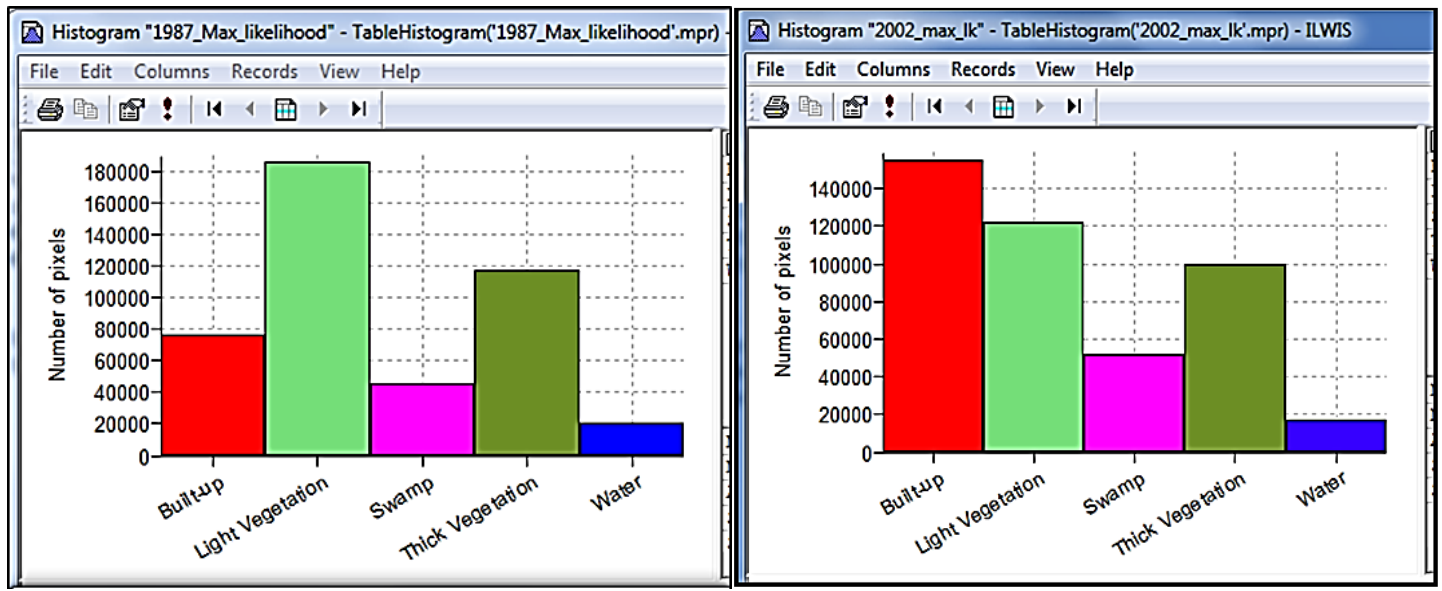

Figure 3. Histogram of Landcover distribution in 1987 and 2002

[Source: Author]

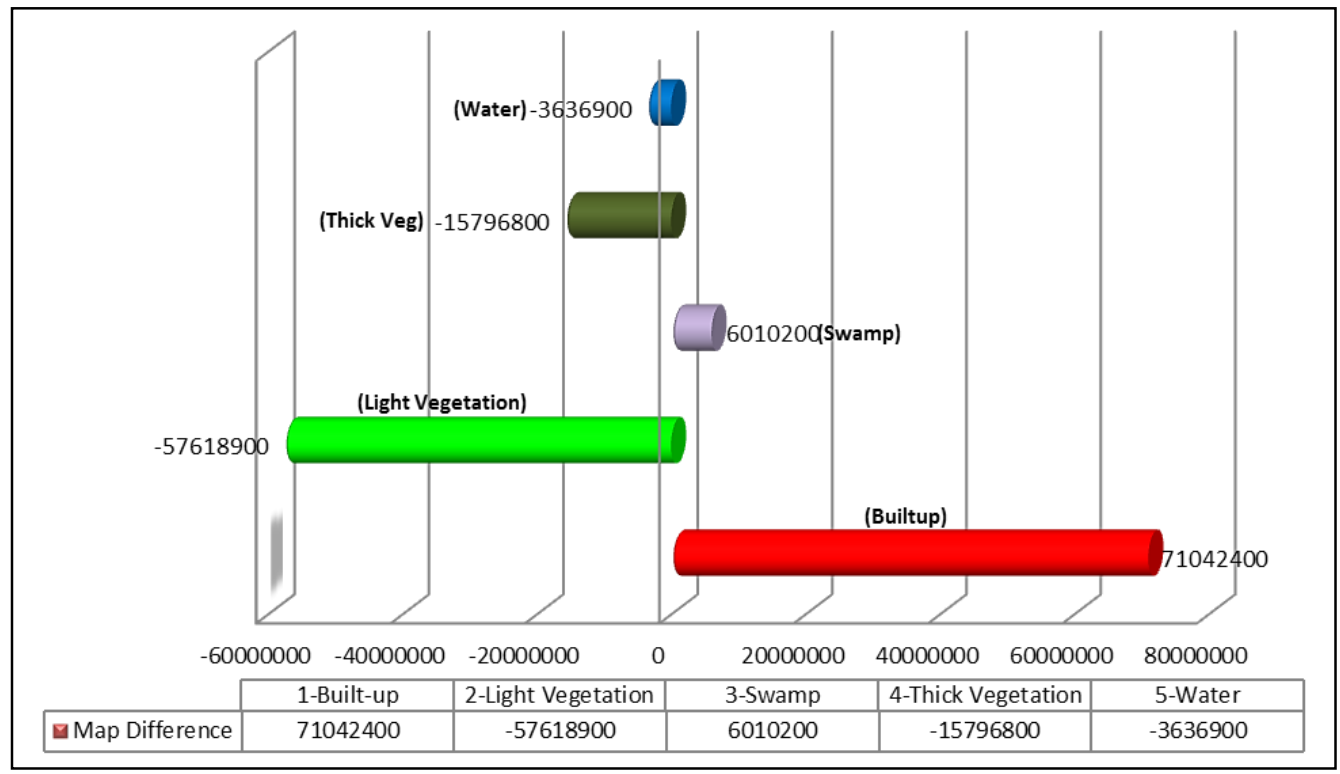

Figure 4. Land Cover Change between 1987 and 2002: Area increase/decrease $\left(\mathrm{m}^{2}\right)$ [Source: Author's Analysis]
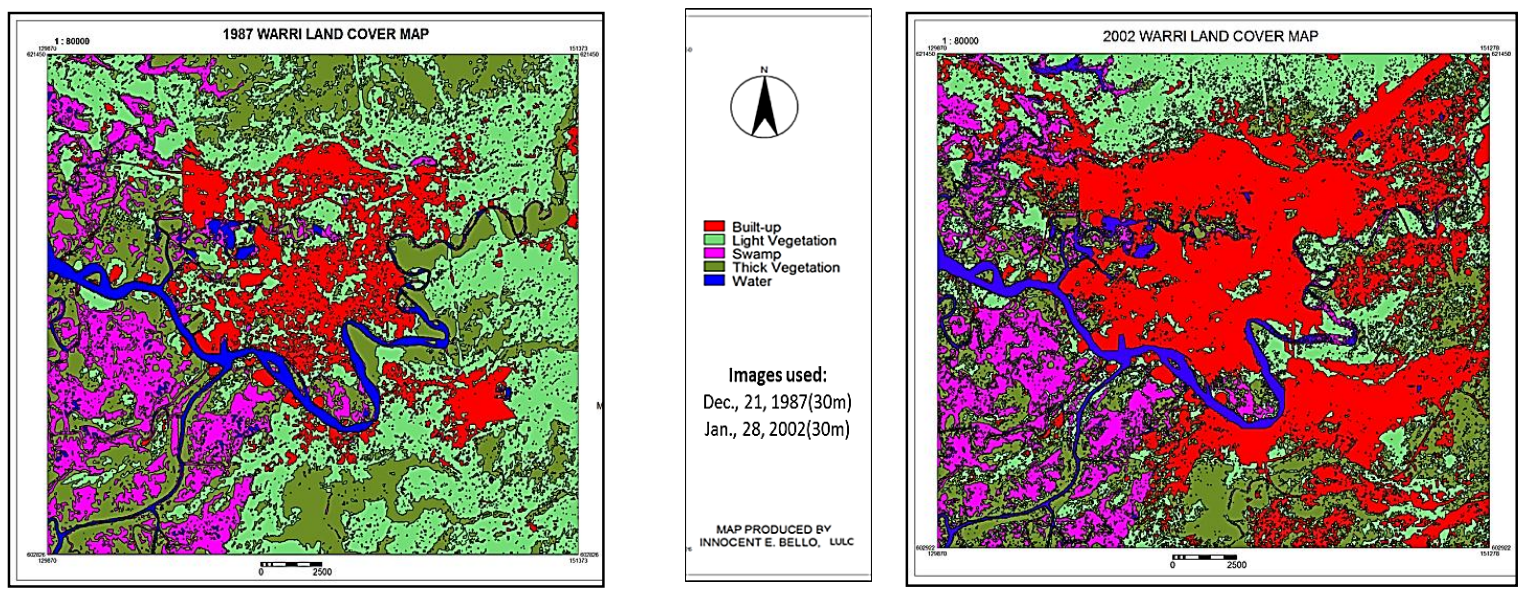

Figure 5. Land Cover Map of Warri and Environs: 1987 (left), 2002 (right) 
The implication of the observed results of classification is that, since 1987 the built-up has been on the increase due to urbanization and socioeconomic activities accentuated by rural-urban migration into the oil city Warri. This has given rise to the cutting down of vegetation cover and incursion into the water ways and swampy areas. Similarly, the increase in swamp is due largely to rainfall and human encroachment into the natural habitat thus pushing the stagnated water mostly from rain-fed and river overflow to expand and fill up new areas thus constituting environment risk.

To assess the accuracy of an image classification, it is common practice to create an error or confusion matrix. An error in remote sensing classification simply implies a mistake resulting from mixed classification.

To assess the accuracy of an image classification, it is common practice to create an error or confusion matrix. An error in remote sensing classification simply implies a mistake resulting from failure to classify an object correctly into a given landcover class (error of omission - accuracy) or classifying what ought not to have been classified in to a given landcover class (error of commission -reliability).

The error of omission is accessed with user accuracy while the error of commission is accessed with producer accuracy. The results are presented as a matrix in a contingency table in row and column for which the sum of row must equal the sum of column variables. In this study, the accuracy assessment for the supervised classification (Tables 4a and 4b) for 1987 and 2002 compared shows an overall accuracy of $96.19 \%$ and $96.30 \%$, producer's accuracy or average accuracy of $95.62 \%$ and $95.14 \%$ and the user's average reliability accuracy of $94.14 \%$ and $92.76 \%$ respectively. The implication of the above results is that the credibility and integrity of the classification result is valid at least to about $96 \%$ on the average. This was conveniently achieved first from PCA transformed coefficients (raster map) and secondly from accurate classification with ground truth a priori knowledge of the study area.

Table 4a. 1987 Classified Image Accuracy Assessment Result [Error Matrix]

\begin{tabular}{lccccccc}
\hline CLASSES & Built-up & Light Veg. & Swamp & Thick Veg. & Water & Unclassified & Accuracy \\
\hline Built-up & 3156 & 25 & 0 & 0 & 0 & 0 & 0.99 \\
Light Veg. & 7 & 1442 & 0 & 120 & 0 & 0 & 0.92 \\
Swamp & 0 & 0 & 809 & 4 & 64 & 0 & 0.92 \\
Thick Veg. & 0 & 140 & 0 & 3443 & 0 & 0 & 0.96 \\
Water & 2 & 0 & 3 & 0 & 366 & 0 & 0.99 \\
Reliability & 1.00 & 0.90 & 1.00 & 0.97 & 0.85 & 0 & \\
& {$[100 \%]$} & {$[90 \%]$} & {$[100 \%]$} & {$[97 \%]$} & {$[85 \%]$} & & \\
\hline
\end{tabular}

Producer's Accuracy $=95.62 \%$, Average Reliability $=94.14 \%$, and Overall Accuracy $=96.19 \%$.

Table 4b. 2002 Classified Image Accuracy Assessment Result (Error Matrix)

\begin{tabular}{lccccccc}
\hline CLASSES & Built-up & Light Veg. & Swamp & Thick Veg. & Water & Unclassified & Accuracy \\
\hline Built-up & 3497 & 2 & 0 & 7 & 0 & 0 & 1.00 \\
Light Veg. & 1 & 595 & 2 & 35 & 0 & 0 & 0.94 \\
Swamp & 0 & 1 & 510 & 0 & 18 & 0 & 0.96 \\
Thick Veg. & 0 & 64 & 0 & 1286 & 0 & 0 & 0.95 \\
Water & 15 & 0 & 135 & 0 & 1393 & 0 & 0.90 \\
Reliability & 1.00 & 0.90 & 0.79 & 0.97 & 0.99 & 0 & \\
& {$[100 \%]$} & {$[90 \%]$} & {$[79 \%]$} & {$[97 \%]$} & {$[99 \%]$} & & \\
\hline
\end{tabular}

Producer's Accuracy $=95.14 \%$, Average Reliability $=92.76 \%$, and Overall Accuracy $=96.30 \%$. 


\section{Conclusion}

In this paper, we emphasized that quantitative techniques are reliable and valid because they employ prescribed procedures in data collection, processing and analysis in geographic research Akinbode [1996] and at the same time eliminate bias in a study because they involve many cases and few variables [Rilwani, 2006]. We also reiterated that quantitative techniques such as PCA analysis are standardized method of handling large data (such as remotely sensed satellite data) because it allow researchers to summarize vast sources of data for better classification as obtained in landuse/landcover, atmospheric and oceanographic studies. As a proof-of-concept, PCA statistical analysis was used to reduce the dimensionality of remotely sensed Landsat images from seven/eight to six bands and then finally to three bands containing the main principal components that gave the best result for 1987, 2002 and 2011 years compared. The 2011 image was further excluded as a result of the scan line error and cloud cover for lack of data quality. Resulting from the PCA analysis, Bands 1-45 gave a variance of 834.71 accounting for $88.09 \%$ of the total components for the 1987, while Bands 1-47 gave a variance of 1287.21 accounting for $85.34 \%$ for the 2002 epoch. The resultant raster map classified helped in having higher accuracies averaging $96 \%$ for each year examined. The resulting change shows an increase in builtup and swamp and a decrease in vegetal and water classes. We argued that urbanization is responsible for man's incursions into the hitherto undisturbed vegetal and swampy area. We recommend urgent control based on the Nigeria's Landuse Act and Development Control (DC) measures while more drainage systems are constructed for proper channelling of water flow as mitigative measures. In conclusion, this paper demonstrates that quantitative method remains a reliable and convincing approach in scientific investigations and results presentation as exemplified using PCA and supervised classification of landcover change detection of Warri and its environs in the Niger Delta region of Nigeria.

\section{References}

Akinbode, A. (1996), Research Methods in Geography. Ekpoma, Edo State University Publishing House.
Balsley, H.L. (1970), Quantitative Research Methods for Business and Economics. New York, Random House.

Bäring, L. (1988), Regionalization of Daily Rainfall in Kenya by Means of Common Factor Analysis. Inernational Journal Climatology. 8, 371-389. http://dx.doi.org/10.1002/joc.3370080405

Bedi, H.S., and Bindra, M.M.S. (1980), Principal Components of Monsoon Rainfall. Tellus, 32, 296-298. http://dx.doi.org/10.1111/j.21533490.1980.tb00956.x

Berry, B.J.L. (1958), A Note Concerning Methods of Classification. Annals of Association of America Geographers, 48(3): 300-303

Cassell, C. and Symon, G. (1994), Qualitative research in work contexts. In C. Cassell, \& G. Symon (Eds.), Qualitative methods in Organizational Research (pp. 1-13). Thousand Oaks, CA, Sage Publications.

Das, R.P. (na). Principal Component Analysis in Multispectral Satellite Images. (Online): http://ficta.in/attachments/article/55/18\%20PR INCIPAL\%20COMPONENT\%20ANALYSIS\% 20IN\%20MULTISPECTRAL\%20SATELLITE \%20IMAGES.pdf, accessed July 19, 2015.

Daultrey, S. (1976), Principal Component Analysis. Norwich Great Britain. Geo. Abstracts Ltd.

Feranec, J., Otahel, J. and Pravda J. (1998), CORINE Land Cover Tourist Map of Slovakia. ITC Journal, 1: 25-30.

Fowdur, S.C., Vir Rughooputh, S.D., Cheeneebash, J., Booghanon, R. and Gopaul, A. (2014). Rainfall Analysis over Maurisius Using Principal Component Analysis. Environmental Management \& Sustainable Development, 3(2): 94-108.

Harris, R., Fitzpatrick, K., Souch, C., Brunsdon, C., Jarvis, C., Keylock, C., Orford, S., Singleton, A. and Tate, N. (2013). Quantitative Methods in Geography: Making the Connections between Schools, Universities and Employers. London, Royal Geographical Society (with IBG).

Helmy, A.K. and El-Taweel, G.S. (2009), Authentication Scheme Based on Principal Component Analysis for Satellite Images. International Journal of Signal Processing, Image Processing and Pattern Recognition. 2(3), $1-10$.

Hotelling, H. (1933). Analysis of a Complex of Statistical Variables into Principal 
Components. Journal of Educational Psychology. 24, 417-441 and 498-520.

Ibe, P.O; Alagbe, A.O and Egharevha, E. (2012), Geospatial Mapping of Vulnerable areas to Flood Hazard and Risk in Warri Metropolis, Warri South Local Government Area, Delta State, Nigeria in: B. Ayeni and O. Fabiyi (eds.) Geospatial Technologies and Digital Cartography for National Securty, Tourism and Disaster Management. Proceedings of Joint Conference of GEOSON/NCA: 19-21 November, 2012. Pp., 197-212. RECTAS, OAU Campus, Ile-Ife, Osun State, Nigeria. Benin City, Mindex Press Limited.

Janos, V. (2009), Applied GIS - Satellite Image Processing. Miskolci Egyetem Földtudományi Kar, (Online): http://www.tankonyvtar.hu/hu/tartalom/tamo p425/0033_SCORM_MFGGT218-

EN/sco_01_02.htm, accessed July 28, 2015.

Jolliffe, I.T. (2002), Principal Component Analysis, Series: Springer Series in Statistics, 2nd ed., Springer, NY, XXIX, 487 p. 28 illus. ISBN 9780-387-95442-4

Kealey, D.J. and Protheroe, D.R. (1996). The Effectiveness of Cross-cultural Training for Expatriates: An assessment of the Literature on the Issue. International Journal of Intercultural Relations. 20(2), 141-165.

Kumar, M. (na), Digital Image Processing. Satellite Remote Sensing \& GIS Application in Agricultural Meteorology, Pp. 81 - 102. (Online): Accessed July 23, 2015, retrieved from http://www.wamis.org/agm/pubs/agm8/Paper5.pdf

Mas, J.F. (1999), Monitoring Land-Cover Changes: A Comparison of Change Detection Techniques. International Journal of Remote Sensing. 20(1), 139-152

Matveev, A.V. (2002), The Advantages Of Employing Quantitative And Qualitative Methods In Intercultural Research: Practical Implications From The Study Of The Perceptions Of Intercultural Communication Competence By American And Russian
Managers in: I.N. Rozina \& Rostov-on-Don (eds.) 'Theory of Communication And Applied Communication'. Bulletin of Russian Communication Association. 1(168), 89 - 67. New York, USA, Institute of Management, Business and Law Publishing

Onokerhoraye, A.G. (1994), Geographic Thought, Philosophy and Methodology. Benin Social Science for Africa. Ibadan, Intec Printers Limited.

Overland, J. E. and Preisendorfer, R.W. (1982), A Significance Test for Principal Components Applied to Cyclone Climatology. Monthly Weather Review. 110, 1-4. http://dx.doi.org/10.1175/15200493(1982)1102.0.CO;2

Pearson, K. (1901), On Lines and Planes of Closest Fit to Systems of Points in Space. Philosophical Magazine, 2 (11), 559-572. doi:10.1080/14786440109462720.

Preisendorfer, R.W. (1988), Principal Component Analysis in Meteorology and Oceanography. New York, Elsevier.

Principal Components Analysis: https://en.wikipedia.org/wiki/Principal_compo nent_analysis

Rilwani, M. L. (2006). Field studies in Geography and Planning. Benin City, Donald publisher

Robinson, A. H. \& Sale, R. D. (1982). Elements of Cartography. $3^{\text {rd }}$ Edition, New York, John Wiley.

Rodarmel, C. \& Shan, J. (2002). Principal Component Analysis for Hyperspectral Image Classification. Surveying and Land Information System. 62(2), 115 -123.

Turner, B.L., Skole, D., Sanderson, S., Fischer, G., Fresco, L. and Leemans, R. (1995), Land-Use and Land-Cover Change; Science/Research Plan, IGBP Report No.35, HDP Report No.7. IGBP and HDP, Stockholm and Geneva.

Wyly, E. (2001), Quantitative Geographical Analysis / Background on Principal Components and Factor Analysis. (Online). Retrieved from http://ibis.geog.ubc.ca/ ewyly/teaching/606_p ca.pdf, accessed July 22, 2015. 